\title{
TAXONOMIC NOTES ON FEATHER MITE SPECIES (ACARIFORMES: ANALGOIDEA) DESCRIBED BY ADOLF EDUARD GRUBE
}

\author{
Sergey V. Mironov ${ }^{1 *}$ and Fabio A. Hernandes ${ }^{2}$ \\ ${ }^{1}$ Zoological Institute, Russian Academy of Sciences, Saint Petersburg, Russia \\ ${ }^{2}$ Departamento de Ecologia e Zoologia, Universidade Federal de Santa Catarina, Florianópolis, \\ Santa Catarina, Brazil \\ "corresponding author; e-mail: sergei.mironov@zin.ru
}

\begin{abstract}
The study presents the results of our re-investigation of feather mite species described by A. E. Grube in 1859 in the genus Dermaleichus Koch, 1841. Grube's paper has been overlooked by most of the $19^{\text {th }}$ and $20^{\text {th }}$ century acarologists. Based on the study of the syntypes of four Dermaleichus species described by the above author, we provide taxonomic comments on them and new synonymies. We conclude the names of three species are valid (senior) synonyms, while one name is a junior synonym. Alloptes (Alloptes) tringae (Grube, 1859) comb.n. (Alloptidae) from Calidris alpina (Charadriiformes: Scolopacidae) is a new senior synonym of Alloptes (s. str.) crassipes (Canestrini, 1878) syn.n.; Analges tergisetis (Grube, 1859) comb.n. (Analgidae) from Pica pica (Passeriformes: Corvidae) is a new senior synonym of Analges corvinus Robin, 1877 syn. n.; Picalgoides caudilobus (Grube, 1959) comb.n. (Psoroptoididae) from Dendrocoptes medius (Piciformes: Picidae) is an older synonym of Dermaleichus picimajoris Buchholz, 1869, D. picipubescentis Packard, 1869, Analges serratilobus Giebel, 1871 and Analges socialis Robin, 1877 (synonymized by Oudemans in 1939, but overlooked by subsequent researchers). Dermaleichus albicillae Grube, 1859 syn.n. from Haliaeetus albicilla (Accipitriformes: Accipitridae) is a junior synonym of Pandionacarus fuscus (Nitzsch, 1818) (Avenzoariidae), a common parasite of Pandion haliaetus (Accipitriformes: Pandionidae).
\end{abstract}

KEY WORDS: Feather mites, Analgoidea, systematics, taxonomy, synonymy.

DOI: 10.21684/0132-8077-2020-28-2-213-220

\section{INTRODUCTION}

In his review entitled "Arachnoiden of Livonia, Kurland and Estland" (presently Latvia, Lithuania and Estonia, respectively), German zoologist Adolf Eduard Grube (1859) described four new feather mite species of the genus Dermaleichus Koch, 1841. This review was published in a little-known journal Archiv für die Naturkunde Liv-, Ehst-und Kurlands (Tartu [Dorpat], Estonia) and was focused primarily on spiders. Most acarologists of the $19^{\text {th }}$ and $20^{\text {th }}$ centuries did not know about this work. Although the descriptions of the new species were brief and not very informative, Grube's illustrations are suitable enough to identify the species of feather mites from a modern taxonomical point of view. Among the subsequent researchers, only Oudemans (1939) provided comments on the aforementioned work and established a new synonymy for one of the species described in that paper.

Surprisingly, ethanol-preserved specimens of the type series used by Grube in the descriptions of his feather mite species were found in the $\mathrm{Mu}$ seum für Naturkunde (Berlin, Germany). Here, we present the results of our study of these specimens and discuss their taxonomic status.

\section{MATERIALS AND METHODS}

Grube's material was deposited in the Museum für Naturkunde (Berlin, Germany) in small glass vials (about $2 \mathrm{ml}$ ) filled with ethanol. The speci- mens had labels, bearing accession collection numbers and host names; catalogue data for these samples indicate that they are "types". Slidemounted type specimens used by Grube (1859) have apparently been lost. Therefore, the remaining ethanol-preserved specimens were mounted for our study and treated as syntypes.

We have mounted several specimens from each vial in Hoyer's medium according to the standard techniques used for small mites (Krantz and Walter 2009). Mite specimens, kept in ethanol for over 160 years, have become very fragile and almost completely desclerotized (transparent). Therefore, prior to mounting, the mites had been softened in $10 \%$ lactic acid at room temperature for 3-5 days. Specimens were studied using Leica DM2500 and DM5000B microscopes (Leica Microsystems, Inc.), equipped with differential interference contrast (DIC) optics. After the identification of slide-mounted specimens, the lectotypes and the paralectotypes were designated in the type series representing valid species. Since the museum specimens were too transparent, our illustrative photos depict comparative specimens of the considered species collected from the corresponding hosts. The collection UFC ZIN No. 2-2.20, deposited in the Zoological Institute of the Russian Academy of Sciences (Saint Petersburg, Russia), was used as a source of comparative material for this study. 


\section{SYSTEMATICS}

Family Alloptidae Gaud, 1957

Subfamily Alloptinae Gaud, 1957

Genus Alloptes Canestrini, 1879

\section{Alloptes (Alloptes) tringae (Grube, 1859) comb.n.}

(Fig. 1A-D)

Dermaleichus tringae Grube, 1859: 51, 65, figs. 5, 6 .

Dermaleichus crassipes Canestrini, 1878: 68 (part.) syn.n.

Alloptes crassipes: Canestrini 1879: 38, tabs. 1-3, fig. 3 (part.); 1886: 293, tab. 44, fig. 4 (part.); Berlese 1888: fasc. 50, No. 5 (part.), 1898: fasc. 88, No. 7 (1); Canestrini and Kramer 1899: 113, fig. 25; Trouessart 1916: 220 (part.); Vitzthum 1929: 102, tab. 10, fig. 52 (part.); Dubinin 1951b: 113, fig. 25 (first reviser, species from Calidris alpina); Gaud 1957: 110 (part.); Gaud and Till 1961: 241 (part.)

Alloptes (Alloptes) crassipes: Gaud 1972: 59; Vasyukova and Mironov 1991: 87, fig. 59.

Type material examined. Male lectotype and 1 male paralectotype (ZMB/Arach 6292) of Dermaleichus tringae Grube, 1859 from Calidris alpina (Linnaeus, 1758) [=Tringa alpina] (Charadriiformes: Scolopacidae), Lithuania, Salantai [Salanty], no date, coll. Hrn. v. Gorski. Lectotype designated here.

Among the mite individuals in the vial that contained the syntypes of Dermaleichus tringae, only two strongly desclerotized males were present. Nevertheless, they were in a satisfactory enough condition to identify them as Alloptes (A.) crassipes (Canestrini, 1878) known from the Dunlin, Calidris alpina. The latter mite species, being the type species of the genus Alloptes, exhibits distinct morphological features. In males, the hysterosoma is shaped as an almost equilateral triangle and the posterior end of the opisthosoma has a distinct ovate enlargement. In females, the opisthosomal lobes are absent, and the opisthosoma is almost rounded (Dubinin 1951b; Gaud 1972; Vasyukova and Mironov 1991) (Fig. 1A, B). Since the name proposed for this mite by Grube (1859) is older than that proposed by Canestrini (1878), we consider the name A. (A.) crassipes (Canestrini, 1878) to be a junior synonym of $A$. (A.) tringae (Grube, 1859) comb.n. The name Dermaleichus tringae Grube, 1859 is not a nomen oblitum because it does not meet both conditions of Article 23.9.1 (ICZN 1999).

With the transfer of Dermaleichus tringae to the genus Alloptes, a secondary homonym, Alloptes gambettae tringae Dubinin, 1951, arises. However, A. gambettae tringae Dubinin, 1951 does not need a replacement name because it is a junior synonym of A. (Conuralloptes) conurus (Trouessart, 1885), already established by Gaud (1972: 64).

Here, we also comment on the identity of A. crassipes. Canestrini (1878) originally described this mite under the name Dermaleichus crassipes from the following four charadriiform birds: $L i-$ mosa limosa (Linnaeus) [ $=$ L. melanura $]$, Phylomachus pugnax (Linnaeus), Calidris alpina (Linnaeus) (Scolopacidae) and Sternula albifrons (Boie, F) [=Sterna minuta] (Laridae). Based on the modern knowledge of the taxonomy and the host associations of the genus Alloptes (Dubinin 1951b; Gaud 1972; Vasyukova and Mironov 1991; Mironov and Palma 2006), it is obvious that Canestrini dealt with several Alloptes species (at least 4), representing different subgenera of Alloptes (Alloptes s.str., Conuralloptes and Sternalloptes). Each of the four host species listed above is known to host a distinct species of the genus Alloptes (Dubinin 1951b; Gaud 1972; Vasyukova and Mironov 1991). However, until the end of the 1950 s, most researchers considered "A. crassipes" a single species associated with many scolopacid hosts (Canestrini 1879, 1886; Berlese 1888, 1898; Canestrini and Kramer 1899; Vitzthum 1929; Gaud 1957; Gaud and Till 1961). Meanwhile, the illustrations of $A$. crassipes provided in some of these works (e.g., Canestrini 1879: pl. 1-3, fig. 3, 1886: pl. 44, fig. 4; Berlese 1888: fasc. 50, No. 5; Vitzthum 1929: fig. 25) clearly show different Alloptes species. Among the publications of that period, only the drawing by Berlese (1888: fasc. 88 , No. 7 , 1) corresponds to the modern taxonomic interpretation of this species. Dubinin (1951b), in his redescription of $A$. crassipes based only on specimens from the Dunlin, Calidris alpina, provided clear diagnostic characteristics and outlined the modern taxonomic identity of this mite species. Therefore, we consider this author to be the first reviser. Subsequent researchers (Gaud 1972; Vasyukova and Mironov 1991) added a few additional diagnostic features to this species (in particular, the structure of the festoons of terminal membranes and the spiculiform seta $m G$ of genu II; Fig. 1C, D) and provided some better illustrations. 


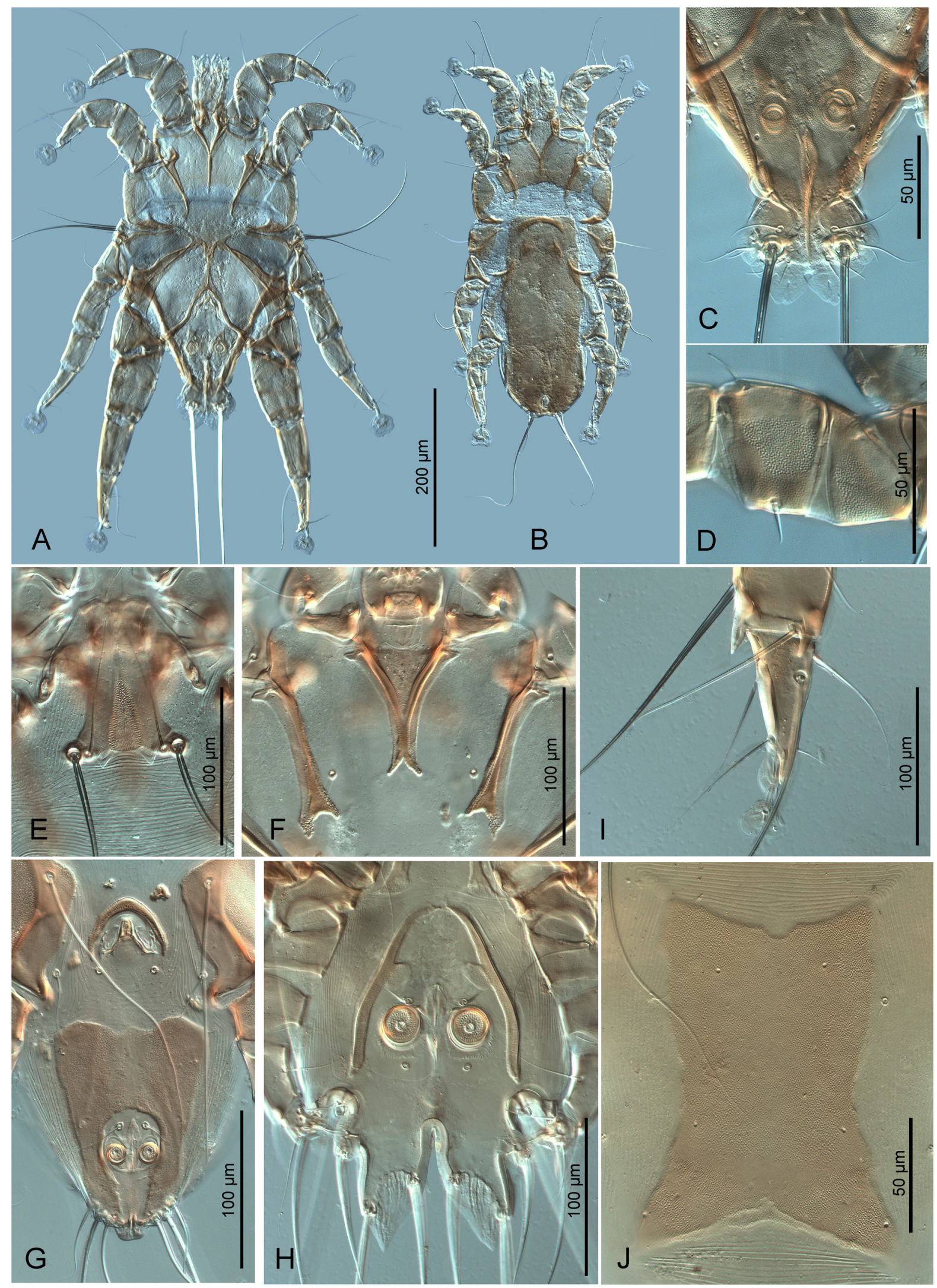

Fig. 1. Morphological details of feather mites. A-D-Alloptes (A.) tringae from Calidris alpina: A-ventral view of male, B - dorsal view of female, C - posterior end of male opisthosoma, D-femur and genu II of male. E-G-Analges tergisetis from Pica pica: E — prodorsal shield of male, F-epimerites I and II of male, G-opisthosoma of male, ventral view. H-J_Picalgoides caudilobus from Dendrocopos major: H—ventral view of male opisthosoma, I—left tibia and tarsus III of male, dorsal view, J—hysteronotal shield of female. 
In his review of the generic content of "Analgesinae", Trouessart (1916) designated A. crassipes as the type species of the genus Alloptes and mentioned the Black-tailed Godwit, L. limosa, as its sole host. However, in our opinion, Trouessart (1916) did not act as the first reviser because merely mentioning a host does not constitute a valid species description, definition or indication (ICZN 1999: Article 12.3). It is also necessary to mention that Gaud (1972) and Vasyukova and Mironov (1991), in fact, followed Dubinin (1951b) as the first reviser and for this reason incorrectly indicated C.alpina as the type host instead of L. limosa, formally designated by Trouessart (1916).

Family Analgidae Trouessart \& Mégnin, 1884 Subfamily Analginae Trouessart \& Mégnin, 1884

Genus Analges Nitzsch, 1818

\section{Analges tergisetis (Grube, 1859)}

(Fig. 1E-G)

Dermaleichus tergisetis Grube, 1859: 64, figs. 7, 8 .

Analges tergisetis: Mironov 2019: 42.

Analges corvinus Mégnin in: Robin and Mégnin, 1877: 503; Berlese, 1886: fasc. 24, No. 4; Canestrini 1886: 285; Oudemans 1897: 258; Canestrini and Kramer 1899: 88; Vitzthum 1939: 86; Dubinin 1951a: 38, 293, figs. 97(1), 115, 131; Mironov 2019: 32, syn.n.

Analges (Analgopsis) corvinus: Gaud 1958: 34, fig. 3A; Gaud and Mouchet 1959: 157, fig. 4b, (part.).

Analges (Analges) corvinus: Mironov, 1985: 173, fig. $6(3,4)$.

Dermaleichus makowski Zimmermann, 1894: 219, syn.n.

Type material examined. Male lectotype, 1 male and 3 females paralectotypes (ZMB/Arach 6295) of Dermaleichus tergisetis Grube, 1859 from Pica pica (Linnaeus, 1758) (Passeriformes: Corvidae) Latvia [Livland], no date, coll. A.E. Grube; 4 female paralectotypes (ZMB/Arach 6294), same collection data. Lectotype designated here.

In the updated world checklist of Analges species, Analges tergisetis (Grube, 1859) from the Eurasian Magpie, Pica pica, and An. corvinus Mégnin, 1877 originally described from the Carrion Crow, Corvus corone Linnaeus, 1758, were treated as separate species (Mironov 2019). The latter mite species was reported from many species of the genera Corvus Linnaeus, Coloeus Kaup and Pica Brisson (Corvidae) throughout the Holarctic region (Robin and Mégnin, 1877; Canestrini and Kramer 1899; Vitzthum 1939; Mironov 1985, 1996; Galloway et al. 2014). After comparing the type specimens of An. tergisetis with numerous specimens formerly identified as An. corvinus (stored in the Zoological Institute of the Russian Academy of Sciences, Saint Petersburg, Russia) from Pica pica and many other corvids of the genera Corvus and Coloeus, we have concluded that these mites are conspecific. Since the name Analges tergisetis is older than An. corvinus, the latter name is treated here as a junior synonym. Among Analges species with tarsus III in males lacking the finger-like process, this mite is well characterized in having the epimerites II with strongly bifurcate ends and the adanal shield with slightly concave anterior margin (Mironov 1985) (Fig. 1F, G).

\section{Family Avenzoariidae Oudemans, 1905 Subfamily Bonnetellinae Gaud and Atyeo, 1981 Genus Pandionacrus Balogh, 1937}

\section{Pandionacarus fuscus (Nitzsch, 1818)}

Analges fuscus Nitszch, 1818: 252; Giebel 1871: 493.

Megninia fusca: Mégnin and Trouessart 1884: 132.

Pteronyssus fuscus: Berlese 1887: fasc. 65, No. 2; Canestrini and Kramer 1899: 84; Oudemans 1937: 2199.

Buchholzia fusca: Trouessart 1916: 217; Bonnet 1924a: 191, figs. 50-52, Vitzthum 1929: 94, pl. 9, fig. 44; Dubinin 1951a: 74, 75, figs. 56, 57.

Bonnetella fusca: Trouessart in: Bonnet, 1924b: 398; Gaud 1983: 730, fig. 2; Gaud and Atyeo 1996: Part II, 69, fig. 80A, B.

Pandionacrus fuscus: Balogh 1937: 206; Özdikmen 2008: 223.

Dermaleichus albicillae Grube, 1859: 66, figs. 1, 1a, 2, syn.n.

Dermaleichus haliaëti Buchholz, 1869: 30, pl. 3, figs. 17, 18, synonymized by Canestrini and Kramer 1899: 84.

Dimorphus haliaëti: Haller 1878: 557, pl. 33, figs. A, B, 1, 4-6, 10, 12-14, 16, pl. 35, figs. A-F.

Material examined. 5 male and 5 female syntypes (ZMB/Arach 6299) of Dermaleichus albicillae Grube, 1859 from Haliaeetus albicilla (Lin- 
naeus, 1758) (Accipitriformes: Accipitridae), Latvia [Livland], no date, coll. A.E. Grube.

Pandionacarus fuscus, the single species of the genus Pandionacarus, is one of the oldest feather mite species described by Nitzsch (1818) in the genus Analges - the first supraspecific taxon of feather mites. This species is easily distinguishable because of its giant size (with body length 1,100 $1,300 \mu \mathrm{m}$ in males and $900-1,000 \mu \mathrm{m}$ in females) (Gaud 1983: 730, fig. 2; Moro et al. 2019: fig. 1). This makes $P$. fuscus one of the three largest feather mites, along with Laminalloptes phaetontis (Fabricius, 1775) and Proterothrix phyllura (Trouessart, 1899), which reach about $1 \mathrm{~mm}$ in length (Atyeo and Peterson 1967; Constantinescu et al. 2018). Pandionacarus fuscus was previously known only from the Osprey, Pandion haliaetus (Linnaeus, 1758), and is common and very abundant on this host: Dubinin (1951a: 302) reported over 12,600 mite individuals on a single bird. Just like this cosmopolitan host, the mite is apparently distributed worldwide (for major references see: Gaud 1983). The examined specimens of Dermaleichus albicillae agree well with the comparative material of $P$. fuscus and its (re)descriptions and illustrations (Buchholz 1869; Haller 1878; Mégnin and Trouessart 1884; Berlese 1887; Dubinin 1951a; Gaud 1983). Therefore, the name given by Grube (1859) is a junior synonym.

Grube (1959) described this species under the name Dermaleichus albicillae from the Whitetailed Eagle, Haliaeetus albicilla (Linnaeus, 1758) (Accipitriformes: Accipitridae). We would like to note the possibility of an accidental contamination either in the course of collecting mites or due to natural factors (e.g., birds occupying recently abandoned nests, where some mites could have accidentally remained from before). Nevertheless, we suggest that a misidentification of the host species or a confusion of Latin names were much more probable. In particular, the spelling of the specific epithet of the Osprey (haliaetus) almost coincides with Haliaeetus (the generic name for sea eagles).

Family Psoroptoididae Gaud, 1958

Subfamily Pandalurinae Gaud and Atyeo, 1982 Genus Picalgoides Černý, 1974

\section{Picalgoides caudilobus (Grube, 1859) comb.n.}

(Fig. $1 \mathrm{H}-\mathrm{J}$ )

Dermaleichus caudilobus Grube, 1859: 66, figs. 3, 4.
Mesalges caudilobus, Oudemans 1939: 188. Dermaleichus picimajoris Buchholz, 1869: 43, pl. 5, figs. 28-30, synonymized by Oudemans 1939: 188.

Dimorphus picimajoris: Haller 1882: 57, pl. 6, figs. 1-3.

Megninia picimajoris: Berlese 1883: fasc. 25, No. 7; Canestrini 1886: 278, pl. 21, fig. 2, pl. 22, fig. 1, 1b; Canestrini and Kramer 1899: 96.

Mesalges picimajoris: Bonnet 1924: 200, figs. 60, 61; Vitzthum 1929: 98; Dibinin 1951a: 10, 33, 38, 87, 91, 129, figs. 77(4), 99(3); 1953: 6, fig. $7 \mathrm{~g}$.

Mesalgoides (Picalgoides) picimajoris: Černý 1974: 250; Mironov 1997: 466.

Picalgoides picimajoris: Mironov 2004: 13, figs. 3b, 4c, 5b, 6b; Mironov et al. 2011: 67, fig. 4A-F.

Dermaleichus picipubescentis Packard, 1869: 493, figs. 2, 3, synonymized by Oudemans 1939: 188.

Analges serratilobus Giebel, 1871: 493, synonymized by Haller 1882: 57 .

Dermaleichus socialis Robin, 1868: 103, nom. nud.

Analges socialis Robin in: Robin and Mégnin 1877: 511, pl. 28, fig. 4, synonymized by Canestrini and Kramer 1899: 96.

Type material examined. Male lectotype, 1 female and 1 tritonymph paralectotypes (ZMB/ Arach 6297) of Dermaleichus caudilobus Grube, 1859 from Dendrocoptes medius (Linnaeus, 1758) (Piciformes: Picidae), Latvia [Livland], no date, coll. A.E. Grube. Lectotype designated here.

Grube (1859) described Dermaleichus caudilobus from the Middle Spotted Woodpecker, Dendrocoptes medius, and the Lesser Spotted Woodpecker, Dryobates minor (Linnaeus), but all specimens from the latter host apparently have been lost. This mite species, to date well known under the name Picalgoides picimajoris (Buchholz, 1869), is common and abundant on many woodpeckers of Europe and North America (Canestrini and Kramer 1899; Oudemans 1939; Mironov 1997, 2004; Mironov et al. 2011; Galloway et al. 2014). After the description by Grube (1859), it was independently described four more times under the following original names: Dermaleichus picimajoris Buchholz, 1869 and Analges serratilobus Giebel, 1871 from the Great Spotted Woodpecker, Dendrocopos major (Linnaeus); Dermaleichus picipubescentis Packard, 1869 from the Downy 
Woodpecker, Dryobates picipubescentis (Linnaeus); and Analges socialis Robin, 1877 from the European Green Woodpecker, Picus viridis Linnaeus. The oldest work by Grube (1859) was unknown to the leading acarologists of that time. Therefore, Canestrini and Kramer (1899) treated D. picimajoris Buchholz, 1869 as a senior synonym over three other mite species described several years later. Oudemans (1939), after establishing that $D$. caudilobus Grube, 1859 was a senior synonym of D. picimajoris Buchholz, 1869 and three other species, gave almost exhaustive synonymies for these mites. However, subsequent researchers did not pay attention to his paper and have until now considered this mite species under the specific epithet "picimajoris" (see synonymies above). After the examination of the material described by Grube and the comparative material, we agree with the taxonomic concept of Oudemans (1939) and consider the valid name for this species to be Picalgoides caudilobus (Grube, 1859) comb.n.

\section{ACKNOWLEDGEMENTS}

We thank Dr. Jason A. Dunlop (Museum für Naturkunde, Leibniz Institute for Research on Evolution and Biodiversity, Humboldt University Berlin, Germany) for searching out Grube's type specimens and loaning the material to us. The study was supported by the Ministry of Science and Higher Education of the Russian Federation (State Registration No. AAAA-A19-119020790133-6) for SVM and by the National Council for Scientific and Technological Development — CNPq (No. 304479/2019-5) for FAH.

\section{REFERENCES}

Atyeo, W.T. and Peterson, P.C. 1967. The feather mite genus Laminalloptes (Proctophyllodidae: Alloptinae). Journal of the Kansas Entomological Society, 40: 447-458.

Balogh, J. 1937. Beiträge zur Acarofauna der Grossen Ungarischen Tiefebene. 1. Acari plumicolae. (Stud. Acar. 6). Acta Litterarum ac Scientiarum Regiae Universitatis Hungaricae Francisco-Josephinae, Szeged, 4(2): 205-207.

Berlese, A. 1882-1903. Acari, Myriopoda et Scorpiones Hucusque in Italia Reperta. Padova and Portici. 101 fasc. DOI: 10.5962/bhl.title.69269

Bonnet, A. 1924a. Révision des genres Megninia, Mesalges et genres voisins de la sous-famille des Sarcoptides plumicoles ( $2^{\mathrm{e}}$ partie). Bulletin de la Société Zoologique de France, 49: 190-218.

Bonnet, A. 1924b. Révision des genres Megninia et Mesalges et genres voisins de las sous-famille des
Sarcoptides plumicoles (Note additionelle). Bulletin de la Société Zoologique de France, 49: 394-398.

Buchholz, R. 1869. Bemerkungen über die Arten der Gattung Dermaleichus Koch. Dresden. 56 pp. + 7 pls.

Canestrini, G. 1878. Nouve specie del genre Dermaleichus. Atti Istituto Veneto di Scienze, Lettere ed Arti, Serie 5, 5: 43-70.

Canestrini, G. 1879. Intorno ad alcuni Acari parassiti. Atti della Società Veneto-Trentina de Scienze Naturali, 6: 32-42+ pls. I-IV.

Canestrini, G. 1886. Famiglia degli Analgesini. Prospetto dell'Acarofauna italiana. Padova, 2: 241$311+$ pls. 19-22.

Canestrini, G. and Kramer, P. 1899. Demodicidae und Sarcoptidae. Das Tierreich, 7: 1-193.

Černý, V. 1974. Parasitic mites of Surinam XIX. Seven new species of Mesalgoides (Analgoidea, Analgidae). Folia Parasitologica, 21: 243-250.

Constantinescu, I.C., Chişamera, G. B. and Adam, C. 2018. Redescription of six feather mite species of the genus Proterothrix Gaud, 1968 (Analgoidea: Proctophyllodidae: Pterodectinae from the "Édouard Louis Trouessart" Collection. Zootaxa, 4486(4): 451-479.

Dubinin, V.B. 1951a. Perevie kleshchi (Analgesoidea). Chast I. Vvedenie v izuchenie [Feather mites (Analgesoidea). Part I. Introduction to study]. Fauna of the USSR, Paukoobraznyye Vol. 6, Fasc. 5. Nauka, Moscow-Leningrad. 363 pp. [In Russian]

Dubinin, V.B. 1951b. Peryevie kleshchi ptits Barabinskoi stepi [Feather mites of birds of the Baraba Steppe. Report I. Feather mites of waterfowl and wading birds of the orders of rails, grebes, palmipedes, anserines, herons, gulls, and limicoles]. Parazitologicheskii Sbornik, 13: 120-256. [In Russian]

Dubinin, V.B. 1953. Peryevie kleshchi (Analgesoidea). Chast II [Feather mites (Analgesoidea). Part II. Families Epidermoptidae and Freyanidae]. Fauna of the USSR, Paukoobraznye, Vol. 6, Fasc. 6. Nauka, Moscow-Leningrad. 412 pp. [In Russian] Galloway, T.D., Proctor, H.C. and Mironov, S. V. 2014. Chapter 5. Chewing Lice (Insecta: Phthiraptera: Amblycera, Ischnocera) and Feather Mites (Acari: Astigmatina: Analgoidea, Pterolichoidea): Ectosymbionts of Grassland Birds in Canada. In: H.A. Cárcamo and D. J. Giberson (Eds.). Arthropods of Canadian Grasslands (Vol. 3): Biodiversity and Systematics Part 1. Biological Survey of Canada, pp. 139-188.

Gaud, J. 1957. Acariens plumicoles (Analgesoidea) parasites des oiseaux du Maroc. I. Proctophyllodidae. Bulletin de la Société de Sciences Naturelles et Physiques du Maroc, 37: 105-136. 
Gaud, J. 1958. Acariens plumicoles (Analgesoidea) parasites des oiseaux du Maroc. II. Analgidae. Bulletin de la Société de Sciences Naturelles et Physiques du Maroc, 38: 27-49.

Gaud, J. 1972. Acariens Sarcoptiformes plumicoles (Analgoidea) parasites sur les oiseaux Charadriiformes d'Afrique. Annales du Musée Royale de l'Afrique Centrale, Série in-8 ${ }^{\circ}$, Sciences Zoologiques, 193: 1-116.

Gaud, J. and Atyeo, W.T. 1996. Feather mites of the World (Acarina, Astigmata): the supraspecific taxa. Musée Royal de l'Afrique Centrale, Annales, Sciences Zoologiques, 277: 1-193 (Pt. 1, text), 1-436 (Pt. 2, illustrations).

Gaud, J. and Mouchet, J. 1959. Acariens plumicoles (Analgesoidea) parasites des oiseaux du Cameroun. II. Analgesidae. Annales de Parasitologie Humaine et Comparée, 34: 149-208.

Gaud, J. and Till, W.M. 1961. Suborder Sarcoptiformes. In: F. Zumpt (Ed.). The Arthropod Parasites of Vertebrates in Africa South of the Sahara (Ethiopian Region). Vol. I (Chelicerata). Publications of the South African Institute of Medical Research, No. L (Vol. IX). Johannesburg, South Africa, pp. 180-352.

Giebel, C. 1871. Ueber die Federmilbengattung Analges Nitzsch. Zeitschrift für die Gesammten Naturwissenschaften, 37: 490-498 + pl. V.

Grube, A.E. 1859. Verzeichniss der Arachnoiden LivKur- und Ehstlands. Archiv für die Naturkunde Liv- Est- und Kurlands, 2 Serie, Biologische Naturkunde, 1: 419-486.

Haller, G. 1878. Weitere Beiträge zur Kenntnis der Dermaleichen Koch's. Zeitschrift für wissenschaftliche Zoologie, 30: 511-562 + pls. XXXIII-XXXV.

Haller, G. 1882. Zur Kenntniss der Dermaleichiden. Archiv für Naturgeschichte, 48: 47-79.

International Commission on Zoological Nomenclature (ICZN). 1999. International Code of Zoological Nomenclature. Fourth Edition. Adopted by the International Union of Biological Sciences. International Trust for Zoological Nomenclature, London. 306 pp.

Krantz, G. and Walter, D. (Eds). 2009. A Manual of Acarology. $3^{\text {rd }}$ edition. Texas Tech University Press, Lubbock. 807 pp.

Mégnin, P. and Trouessart, E.L. 1884. Note sur la morphologie et sur la classification des Sarcoptides plumicoles. Bulletin de la Société d'Etude Scientifiques d'Angers, 12: 131-139.

Mironov, S. V. 1985. Peryevye kleshchi rodov Analges i Pteronyssoides Evropeiskoi chasti SSSR (Sarcoptiformes, Analgoidea) [Feather mites of the genera Analges and Pteronyssoides from the European part of the USSR (Sarcoptiformes, Analgoidea)]. Parazitologicheskii Sbornik, 33: 159208. [In Russian with English summary]

Mironov, S.V. 1996. Peryevye kleshchi vorobyinykh severo-zapada Rossii [Feather mites of the passerines in the North-West of Russia]. Parazitologiya, 30(6): 521-539. [In Russian with English summary].

Mironov, S. V. 1997. Contribution to the feather mites of Switzerland with descriptions of five new species (Acarina: Sarcoptiformes). Mitteilungen der Schweizerischen Entomologischen Gesellschaft, 70: 455-471.

Mironov, S. V. 2004. Taxonomic notes on four genera of the feather mite subfamily Pandalurinae (Astigmata: Psoroptoididae). Acarina, 12(1): 3-16.

Mironov, S. V. 2019. A new species of the feather mite genus Analges Nitzsch, 1818 (Acariformes: Analgidae) from the Streaked Spiderhunter Arachnothera magna (Passeriformes: Nectariniidae), with a renewed diagnosis and world checklist to the genus. Acarina, 27(1): 19-43.

Mironov, S.V. and Palma, R. 2006. Two new feather mite species (Acari: Analgoidea) from the Tuamotu Sandpiper Aechmorhynchus parvirostris (Charadriiformes: Scolopacidae). Tuhinga-Records of the Museum of New Zealand Te Papa Tongarewa, 17: 49-59.

Mironov, S. V., Literák, I., Sychra, O. and Čapek, M. 2011. A new feather mite species of the genus Picalgoides Černý, 1974 (Astigmata: Psoroptoididae) from a passerine host in Costa Rica. Systematic Parasitology, 79: 63-70.

Moro, M.M.L.A., Waquim, E.C., Melo-Evangelista, L.S. and Hernandes, F.A. 2019. Feather mites (Acari: Astigmata) of the Zoobotanical State Park in Teresina, Brazil. Acarologia, 59(4), 424-432. DOI: $10.24349 /$ acarologia/20194345

Nitzsch, C.L. 1818. Acarina, Acarus, 1: 246-252. In: J.S. Ersch and J.G. Gruber (Eds.). Allgemeine Encyclopädie der Wissenschaften und Künste. Leipzig, pp. 246-252.

Oudemans, A.C. 1897. List of Dutch Acari, 7 part: Acaridiae Latr., 1806, and Phytoptidae Pagenst., 1861 , with synonymical remarks in descriptions of new species. Tijdschrift voor Entomologie, 40: 250-269.

Oudemans, A.C., 1937. Kritisch Historisch Overzicht der Acarologie (Vol. 3, 1805-1850, Band E, F). E. J. Brill, Leiden. 3379 pp. + ci.

Oudemans, A.C., 1939. Nieuwe Funde auf dem Gebiete der Systematik und der Nomenklatur der Acari. VII. Zoologischer Anzeiger, 127: 184-190. 
Özdikmen, H. 2008. Nomenclatural changes for a family group name and twelve genus group names in Acari. Munis Entomology and Zoology, 3(1): 217-230.

Packard, A.S. Jr. 1869. A chapter on mites. American Naturalist, 3(7): 364-373+ pl. 6.

Robin, C. 1868. Mémoire sur les Sarcoptides avicoles et sur les métamorphoses des Acariens. Compte Rendu Hebdomadaire des Séances de l'Académie des Sciences, Paris, 66: 776-787.

Robin, C. and Mégnin, P. 1877. Mémoire sur les Sarcoptides plumicoles. Journal de l'Anatomie et de la Physiologie Normales et Pathologiques de l'Homme et des Animaux. Paris, 13: 209-248, 391-429, 498-520, 629-656 + pls. XII, XIII, XXII-XXIX, XXXVI-XXXVIII.
Trouessart, E.L. (1915) 1916. Révision des genres de la sous-famille des Analgesinae, ou Sarcoptides plumicoles. Bulletin de la Société Zoologique de France, 40: 207-223.

Vasyukova, T.T. and Mironov, S.V. 1991. Perevye kleshchi guseobraznykh i rzhankoobraznykh Yakutii. Sistematika. [Feather mites of Anseriformes and Charadriiformes of Yakutia. Systematics]. Nauka, Siberian Department, Novosibirsk. 200 pp. [In Russian]

Vitzthum, H. 1929. 5. Ordung: Milben, Acari. Die Tierwelt Mitteleuropas, 3: 1-112+ pls. 1-12.

Zimmermann, H. 1894. Einige neue Arten aus der Familie der Federmilben. Verhandlungen des Naturforschenden Vereins in Brünn, 32: 211-230. 